\title{
Enterovesical Fistula Complicating Myomectomy: A Case Report
}

\author{
K. C. Ekwedigwe, I. Sunday-Adeoye, S. Lengman, M. E. Isikhuemen, A. B. C. Daniyan, E. N. Yakubu, \\ M. O. Eliboh, I. E. A. Uguru
}

National Obstetric Fistula Centre, Abakaliki, Nigeria

Email: *maradona4real2002@yahoo.com

How to cite this paper: Ekwedigwe, K.C., Sunday-Adeoye, I., Lengman, S., Isikhuemen, M.E., Daniyan, A.B.C., Yakubu, E.N., Eliboh, M.O. and Uguru, I.E.A. (2017) Enterovesical Fistula Complicating Myomectomy: A Case Report. Open Journal of Urology, 7, 75-78.

https://doi.org/10.4236/oju.2017.74010

Received: January 10, 2017

Accepted: April 25, 2017

Published: April 28, 2017

Copyright $\odot 2017$ by authors and Scientific Research Publishing Inc. This work is licensed under the Creative Commons Attribution International License (CC BY 4.0).

http://creativecommons.org/licenses/by/4.0/

\begin{abstract}
Background: Enterovesical fistula is an abnormal communication between the bladder and the gastrointestinal tract. It is an uncommon type of genital fistula, occasionally complicating pelvic surgeries. However, it is the most common type of fistula associated with diverticular disease of the colon. Other causes include cancer, trauma and iatrogenic injuries. Pneumaturia and fecaluria usually implies enterovesical fistula. Enterovesical fistula complicating myomectomy is an uncommon finding. Our aim is to report a case of enterovesical fistula following myomectomy. Case presentation: She is a 33-yearold nullipara who presented at the National Obstetric Fistula Centre, Abakaliki, Ebonyi State, South-Eastern Nigeria with a history of fecaluria, pneumaturia and haematochezia which started after myomectomy. Feculent fluid was obtained on urethral catheterization. Cystography was suggestive of enterovesical fistula. Conclusion: Enterovesical fistula is a possible complication of myomectomy. A high index of suspicion for this rare but potentially devastating condition is important for early diagnosis and appropriate management.
\end{abstract}

\section{Keywords}

Enterovesical Fistula, Myomectomy, Uterine Fibroid

\section{Introduction}

Enterovesical fistula is an abnormal communication between the intestine and the bladder and may markedly affect patients quality of life [1]. Historically, enterovesical fistula was described by Rufus of Ephesus as early as the second century $\mathrm{AD}[2]$. It is an uncommon disease which occurs most frequently in advanced stage malignancies or from traumatic or iatrogenic injuries [1]. Based on the bowel segment involved, it can be divided into colovesical (the commonest form), rectovesical, ileovesical and appendicovesical fistula [3]. Diverticulitis is 
the most common aetiology which accounts for $50 \%-70 \%$ of cases [3].

Although the pathology is usually of intestinal origin, the majority of problems are referred to the urologist because of urological symptoms [4]. Pneumaturia, fecaluria and recurrent urinary tract infections are common methods of presentation in enterovesical fistula [5] [6]. Diagnosis of this disease is sometimes challenging and patients may be monitored for months before recognition of this disease [3].

Myomectomy involves surgical removal of uterine fibroid. Several complications could follow this procedure but enterovesical fistula is an uncommon complication. Our aim is to present a case of enterovesical fistula following myomectomy.

\section{Case Report}

She is a 33-year-old nullipara who presented at the National Obstetric Fistula Centre, Abakaliki, Ebonyi State, South-Eastern Nigeria with a history of fecaluria and pneumaturia which started a year after myomectomy. She had myomectomy for symptomatic uterine fibroid in a tertiary health facility in Nigeria and subsequently presented to our health facility three years later with these symptoms. She also gave a history of associated lower abdominal pain. There were no other co-morbidities.

On examination, patient was pale (packed cell volume was 29\%). Pfannensteil scar was noted. The uterus was eighteen-week size. Feculent fluid was obtained on urethral catheterization. Based on the above findings, an assessment of enterovesical fistula was made. She was placed on haematinics and packed cell volume appreciated to $31 \%$ after three weeks.

Cystogram done for her showed leakage of contrast into the bowel. There was no leakage into the uterus. The diagnosis of enterovesical fistula was sustained. Abdominopelvic ultrasound done showed multiple uterine fibroid. Hysterosalpingogram showed that there was no spillage of contrast in both tubes.

Patient was counselled and subsequently had laparatomy for repair of enterovesical fistula after adequate bowel preparation. Findings at surgery were extensive adhesion of the gut, bladder, uterus and anterior abdominal wall. Enterovesical fistula was demonstrated and uterine myoma was also noted. Adhesiolysis was done. The bladder, bowels and uterus were separated. The bowel and bladder were repaired separately in two layers with absorbable suture. The peritoneum was irrigated with normal saline. Rectus sheath and abdomen were then closed. Patient was placed on analgesics and antibiotics in the postoperative period.

\section{Discussion}

The intestinal origin of enterovesical fistula includes the sigmoid colon, rectum, ileum, descending colon, transverse colon and ascending colon [5]. Majority of cases of colovesical fistula are from diverticular disease [6]. Other causes include colon cancer, crohn's disease, surgeries and actinomycosis [5] [6] [7] [8]. It is 
less common in females because there is interposition of the female reproductive organs between the colon and the bladder [9].

Enterovesical fistula is diagnosed primarily by clinical findings [5]. Presenting features include fecaluria, pneumaturia and recurrent urinary tract infection [5] [6] [7]. Other symptoms are dysuria, urinary frequency, haematuria, haematochezia, diarrhoea, alteration of bowel habit, urinary flow via the rectum and abdominal pain [5] [7] [10]. Our patient had fecaluria, pneumaturia and lower abdominal pain. Based on these findings, a clinical diagnosis of enterovesical fistula was made.

A high index of suspicion is required to prevent a delay in the diagnosis of this disease condition. As seen in this case report, diagnosis and surgical repair of enterovesical fistula was done three years after myomectomy. She made several hospital visits in other health facilities with these complaints but the diagnosis was not made. Being a rare complication of myomectomy, a surgeon may not entertain this diagnosis early enough, unless from a high index of suspicion.

Imaging studies for enterovesical fistula includes cystography, computerized tomography, ultrasonography and magnetic resonance imaging [1] [3] [11]. The cystogram of our patient showed leakage of contrast into the bowel which was indicative of enterovesical fistula.

Treatment of enterovesical fistula can be conservative or surgical. Non operative management of enterovesical fistula may be an option in non toxic, minimally symptomatic patients with non malignant disease [1]. Operative management of enterovesical fistula is dependent on the aetiology, site of the bowel lesion, and patients preoperative status [1]. Our patient had surgical repair of enterovesical fistula and was lost to follow up.

\section{Conclusion}

Enterovesical fistula is an uncommon but possible complication of myomectomy. Diagnosis can be made clinically. However, a high index of suspicion is needed to prevent delay in this disease condition. Typical symptoms of this disease are fecaluria and pneumaturia.

\section{Consent}

Consent was obtained from the patient for publication of this article.

\section{References}

[1] Golabek, T., Szymanska, A., Szopinski, T., Bukowczan, J., et al. (2013) Enterovesical Fistula: Aetiology Imaging and Management. Gastroenterology Research and Practice, 2013, Article ID: 617967

[2] Basler, J. and Adekoya, E. Enterovesical Fistula. Available from http://www.medscape.com/

[3] Scozzari, G., Arezzo, A. and Morino, M. (2010) Enterovesical Fistulas: Diagnosis and Management. Techniques in Coloproctology, 14, 293-300.

https://doi.org/10.1007/s10151-010-0602-3 
[4] Vesicoenteric Fistula. Urologic Surgery. https://urologysurgery.wordpress.com

[5] Kavanagh, O., Neary, P., Dodd, J.D., Sheahan, K.M., et al. (2005) Diagnosis and Treatment of Enterovesical Fistula. Colorectal Disease, 7, 286-291. https://doi.org/10.1111/j.1463-1318.2005.00786.x

[6] Daniels, I.R., Bekdash, B., Scott, H.J., Marks, C.G. and Thamas, W.M. (2002) Diagnostic Lesions Learnt from a Series of Enterovesical Fistula. Colorectal Disease, 4, 459-462. https://doi.org/10.1046/j.1463-1318.2002.00370.x

[7] Garcea, G., Majid, I., Sutton, C.D., Pattenden, C.J. and Thomas, W.M. (2006) Diagnosis and Management of Colovesical Fistula; Six-Year Experience of 90 Consecutive Cases. Colorectal Disease, 8, 347-352. https://doi.org/10.1111/j.1463-1318.2005.00928.x

[8] Euanorasetr, C., Suwanthanma, W. and Sornmayura, P. (2010) Enterovesical Fistula Associated with Pelvic Actinomycosis: Case Report and Literature Review. The Thai Journal of Surgery, 31, 18-22.

[9] Yu, N.C., Raman, S.S., Patel, M. and Barbaric, Z. (2004) Fistulas of the Genitourinary Tract: A Radiologic Review. Radiographics, 24, 1331-1352.

[10] Najjar, S.F., Jamal, M.K., Savas, J.F. and Miller, T.A. (2004) The Spectrum of Colovesical Fistula and Diagnostic Paradigm. The American Journal of Surgery, 188, 617-621.

[11] Priya, K., Chandru, R. and Ramya, R. (2013) Colovesical Fistula: A Case Report and Review of Literature. SRJM, 6, 24-26.

Submit or recommend next manuscript to SCIRP and we will provide best service for you:

Accepting pre-submission inquiries through Email, Facebook, LinkedIn, Twitter, etc. A wide selection of journals (inclusive of 9 subjects, more than 200 journals)

Providing 24-hour high-quality service

User-friendly online submission system

Fair and swift peer-review system

Efficient typesetting and proofreading procedure

Display of the result of downloads and visits, as well as the number of cited articles

Maximum dissemination of your research work

Submit your manuscript at: http://papersubmission.scirp.org/

Or contactoju@scirp.org 